\title{
National Identity and Multiculturalism: A Critical Analysis of Lloyd Fernando's Scorpion Orchid
}

\author{
Riyad Abdurahman Manqoush
}

Associate professor of English literature, English Language Department, College of Education, Seiyun University, Hadhramout, Yemen.

\begin{abstract}
This paper is intended to examine the issue of identity in Malaya at the first half of the twentieth century as exposed in Lloyd Fernando's Scorpion Orchid (1976). The novel centers on four friends from different races in Malaya mainly Malay, Indian, Chinese and European. The analysis is supposed to highlight the problems and issues of nationhood and nationalism that are reflected in the text. In other words, the research explores the characters' sense of belonging as well as their national identity to their homelands and their suffering in the hostland, Malaya. The analysis of this study is theoretically framed based on Hami Bhabha's Nation and Narration (1990). The discussions and analysis conclude that the issues of nationhood and nationalism have evidently been exposed in Fernando's Scorpion Orchid. One of the characters-Sabran-attempts to unite the students from the different races in one union to liberate Malaya from the colonizers. He strengthens his relationships with his friends and confirms that all people from different races should accept each other and live together. Similarly, another character-Sally-can be seen as a symbol of the land for she loves all people who visits her the same way that Malaya loves the different races who inhabit it. Even though Sally and Malaya have happily welcomed the different races, both have not been given love in return. However, Peter's suffering of racial prejudice symbolizes the Eurasians of Malaya at that time when they were discriminated and stereotyped as Europeans just because they were white. Due to that racial prejudice and alienation, Peter feels that he does not belong to Malaya and thus he decides to travel to England at the end of the novel. Just like Peter, Santinathan's uncle and family leaves Malaya and return to their homeland, India. In short, the novel is one of the marvelous texts that portray the multicultural society of Malaya in the 1950s. It mirrors the experiences of the different races-the Malays, Indians, Chinese and Eurasians-who lived in Malaya. In other words, the novel uncovers the identity problem of those races including their sense of belonging and living in between spaces.
\end{abstract}

Keywords — Lloyd Fernando, Scorpion Orchid, national identity, sense of belonging, living in between spaces.

\section{INTRODUCTION}

This paper is intended to examine the issue of identity in Malaya at the first half of the twentieth century as exposed in Lloyd Fernando's Scorpion Orchid (1976). The novel centers on four friends from different races in Malaya mainly Malay, Indian, Chinese and European. The analysis is supposed to highlight the issues of nationhood and nationalism that are reflected in the text. In other words, the research explores the characters' sense of belonging and national identity to their homelands as well as their suffering in the hostland, Malaya. The discussions and analysis of this study have theoretically been framed based on Hami Bhabha's Nation and Narration (1990).

The word "Malaya" refers to what was called as the British Malaya at the period of time from the eighteenth century until the fifties of the twenty century. It also refers to the Federation of Malaya which appeared from 1946 until 1963. Later on, and specifically from 1963 till the present, the word "Malaya" refers to the states of Malaya or the Malay Peninsula which include "Malaysia, Southern Thailand, and the southernmost tip of Myanmar ... as well as the city state of Singapore" (Wikipedia, 2020). 
Lloyd Fernando was born in 1926 and he is one of the most famous writers in Malaya. Mohammad Quayum (2006) reveals that "Lloyd Fernando was born in Sri Lanka in 1926, and in 1938, at the age of twelve, he migrated to Singapore with his family." Quayum (2006) also illustrates the beginning days of Fernando in Singapore where the author 'continued his schooling at St Patrick's but the Japanese occupation of Singapore from 1943 to 1945 dealt a severe blow, interrupting his formal schooling, and, most tragically, costing his father's life in one of the Japanese bombing raids." His father's death was a change point in his live. According to Quayum (2006), "following his father's death, Fernando started working as trishaw rider, construction laborer and apprentice mechanic, to support himself and the family." After the war, Fernando completed his Cambridge School Certificate and worked as a school teacher (Quayum 2006). In 1955, he entered the University of Singapore and he graduated in 1959. In fact he studied both English and Philosophy (Quayum 2006). In 1960, he joined the Department of English in the University of Malaya, Kuala Lumpur as an assistant lecturer. After he had studied Ph.D at the University of Leeds in England, he came back to the University of Malaya. In 1967, he "was elevated to Professor and Head of English at the University of Malaya, posts he held until 1979" (Quayum 2006). In fact, Fernando started writing fiction approximately in the 1970s. He wrote two novels Scorpion Orchid (1976) and Green is the Colour (1993). In addition to that, he edited several anthologies. With settings based on authentic historical situations, his novels reflect social and political issues that are aroused in a young nation struggling to find its own identity.

According to Cheah Wei Lyn (2006:1), a person who reads "Fernando's novels can be easily alerted to the issues and concerns of people who struggle with the process of forming a new nation." This merit has spurred critics and scholars to shed light on Fernando's literary works. For instance, Fadillah Merican et al. (2004:124) elaborate that Fernando's stories do not end on a note of 'Edenic' possibilities. It seems that Fadillah's argument is true because in Fernando's works there is no indication of how the future of the nation will be. In addition to that, based on Fernando's works, Lyn (2006: 1) illustrates that "one gets the idea that the future depends on the passion and determination of the characters." Fernando's works reflect his own concerns about the future of Malaya and its ultimate destiny as a nation (Quayum 2001:168). Besides, they draw attention to "the moral and sociological problems of a country newly independent from its Western colonizers" (Lyn 2006:2).
Moreover, Koh (2001:155) reveals that the characters in the novel, Scorpion Orchid, that are really of different racial backgrounds desire to understand their ancestry and at the same time try to find a common ground that binds them together. They "realize that the ideal world that was filled with understanding was merely an illusion" (Lyn 2006:2). Thus, all of them start to feel that the "futility and desire for flight co-exist with a search for a meaningful identity and a place that could be regarded truly as home" (Koh 2001:155). Lyn (2006:2) writes that "Fernando is also a unique and unlike other Malaysian writers because his novels comprise of characters from different ethnic backgrounds." In fact, a large number of Malaysian writers are more comfortable writing about the experience of the community they know best i.e. their own community. Lyn (2006:2) also adds that Fernando, in his works, "reveals that the nation that each racial group is not alone in its search for an identity in the new land." That is why his works emphasizes on the unity of the nation.

However, Collin Abraham (1997) elaborates that the racial division was terminated by the colonizers. It was this very diversity within the colonial situation that was used by the colonizers to maintain domination. Moreover, Abraham (1997) continues that the division resulted in a heightened racial tension and conflict; Fernando includes them as a foreground for the development of the characters and also to bring out the personal and inner struggle of each character as they respond to the chaos around them (Lyn 2006:2).

\section{THEORETICAL BACKGROUND}

Fernando's Scorpion Orchid reflects the Malayans' search for identity and explores their sense of belonging. The national identity and the sense of belonging to the land emphasize on the national feeling as well as nationalism. Consequently, the analysis of the novel requires a sufficient knowledge of the word 'nation.' According to John McLeod (2000: 210), "The concept of 'home' often performs an important function in our lives. It can act as a valuable means of orientation by giving us a sense of our place in the world. It tells us where we originated from and where we belong. As an idea it stands for shelter, stability, security and comfort." McLeod (2000: 210) later on adds: "To be 'at home' is to occupy a location where we are welcome, where we can be with people very much like ourselves." Based on that, homeland is like a mother who feeds her children and gives them love and happiness; it is not merely a geographical place; it is culture, history, family, relatives, and neighbors. In fact, the sense of belonging to a particular nation is an exciting sense that most of the people around the world have. 
Mar-Apr 2020 /Available online: https://ijels.com/

By the same token, Adnan Mohammad Zarzour (1999:43) illustrates that 'the word 'nation' refers to a group of people who speak one language and have the same origin such as the Arabs, the Persians, and the Turks." These shared elements make them one nation. However, the British cultural historian, Raymond Williams, identifies the 'nation' "as a term radically connected with "native'." He adds that "we are born into relationships which are typically settled in a place" (Williams 1983; Bhabha 1990:45). However, the two definitions that are discussed previously seem to be imperfect and insufficient to explain the meaning of the word 'nation.' Since the word 'nation' is ambiguous and it might involve various meanings, Ernest Renan (1990:19, in Bhabha 1990:19) provides, in the quotation below, its comprehensive definition in which he argues;

A nation is a soul, a spiritual principle. Two things, which in truth are but one, constitute this soul or spiritual principle. One lies in the past, one in the present. One is the possession in common of a rich legacy of memories; the other is present-day consent, the desire to live together, the will to perpetuate the value of the heritage that one has received in the undivided form. (Renan 1990:19, in Bhabha 1990:19).

As exposed in the excerpt above, unlike Zarzour's definition of the nation that focuses on the language and the origin, Renan (1900:19, in Bhabha 1990:19) elaborates some extra elements that people should share in order to become a nation. They are supposed to have the desire to live together. Besides, they have to share the same heritage as well as the similar memories.

Similarly, Kamaludin Rifaat (1966) argues that the term 'nation' refers to "a particular group of people who might be different to a certain extent but they all together share some characteristics, features, and elements such as a specific language, geographical land, history, interest, and similar ideology." Hence, if these elements are shared by group of people, even though they are from different countries, those people can be identified as a nation. In addition to that, Gastanteen Zureiq (1994) scrutinizes that 'the 'nation' is a group of people who share some elements and features such as language, culture, history, ambition, pain, and interest." These elements contribute together to make that group of people a united nation. People may also share some myths that are relevant to the culture and history. In fact, the word 'myth' conveys an ambiguous meaning as well. For instance, Timothy Brennan (1990:42) identifies the word 'myth' as a "distortion or lie; myth as mythology, legend, or oral tradition; myths as literature prose; myths as shibboleth." The correlation between the nation and the myths reinforces the national sense of belonging. It creates the national identity that is, later on, shaped as 'nationalism.'

Pertaining the previous discussions, Brennan (1990: 57) identifies the term 'nationalism' as "a state of mind in which the supreme loyalty of the individual is felt to be due to the nation-state." In spite of the national enthusiasm that nationalism connotes, "most commentators agree that the idea of nation is western in origin. It emerged with the growth of western capitalism and industrialization and was a fundamental component of imperialist expansion" (McLeod 2000:68). Even though the concept of nationalism was first created in the west, it has been developed in the East.

Thus, the 'nation' can indeed be identified as a group of people who share some characteristics, elements, and components that make them feel they are connected to each other. They experience the same history and inhabit in the same land or perhaps in attached lands, adopt analogous ideology and ambitions.

\section{DICUSSIONS AND ANALYSIS}

Scorpion Orchid was set in Malaya in 1950s. It centers mainly on four young men, Guan Kheng, Sabran, Santinathan and Peter. The four characters struggle to live in Malaya during the racial riots. They meet at the university and unite in their hopes of an ideal Malaya. The novel begins with old uncle Rasu taking his family back to India. The situation in Malaya is unstable and there are rumors of social unrest. He allows his nephew, Santinathan, to remain in Malaya in order to complete his university study. The family also leaves Santinathan's sister-Neela — because she refused to return to India with them. Santinathan is supposed to go back to India with his sister after he graduates. However, in the last year of their study, the racial riots break out and each one of the four friends is affected. Sabran becomes involved in a students' union and tries his best to combine students' union composed of the different races in the students. However, as he carries out his 'mission' he is aware that the unions he strives to combine are fighting for different reasons. During the riots, he is detained by police for suspicion of spreading rumors. Conversely, Santinathan rents a room after his family leaves Malaya. He continues attending the university until he is expelled for improper conduct. He then leaves the university. One day, his sister-Neelavisits him. She is pregnant with a university lecturer's child-Ellman. Santinathan and Neela now recall their past in India before their father brought the family to Malaya. They realize that as much as they enjoyed their childhood in India, their motherland holds nothing for them now. 


\section{Mar-Apr 2020 /Available online: https://ijels.com/}

Later, Santinathan witnesses a brutal murder of a Eurasian man. He has been shocked and troubled. Consequently, he falls ill for some days. During the riots, Guan Kheng realizes that he does not feel at home in Malaya. He thinks about the different races that live in the country and decides that it is foolish to expect unity from a people so diverse. He falls back on his Chinese education. Although he may have forgotten some Chinese customs, he has retained enough to identify himself as Chinese. He attributes his calm and poise during the riots to his Chinese education. He knows who he is and his position in the country during the situation. In contrast, Peter, throughout the novel, constantly talks about going back to England. He feels he does not belong to Malaya. He thinks that he will be accepted in England or Australia. He even traces his lineage to prone he is more than $51 \%$ white so that he can migrate. During the riots, he is attacked. This strengthens his decision to move away from Malaya. He is contrasted with his mother, Mrs. D'Almeida. She is quite comfortable living among the locals and relishing local condiments like sambal and belachan. In other words, she is different from her son.

As the four friends struggle with their revelation of their own identity during the racial riots, they drift apart. However, they realize that their close friendship is on a superficial level. They did not really know each other. They began to see themselves as separate entities in the society and find it more and more difficult to reach common ground.

Conversely, the four students are linked to two mysterious characters - Sally and Tok Said. Sally is a prostitute to whom is admired by all of them. She accepts them for who they. However, when she is assaulted during the riots, they abandon her. Consequently, she disappears from their lives.

Sally and the four friends are acquainted with Tok Said. None of the characters is able to tell what race Tok Said is. To Sally, he is an old Indian man. To Santinathan, he is Malay. To Guan Kheng, he could be Malay, Chinese, Indian or Eurasian. Although his racial background is not determined, those who meet him take his messages quite seriously. Santinathan is troubled when Tok Said tells him that he will die that year. Sally is distraught when Tok Said says she must love all who come to her. Sabran hears Tok Said telling him not to lose heart. Conversely, Guan Kheng meets a toothless man who tells him nothing. In general, they are all are preoccupied by him.

While the people of Malaya experience uncertainty and fear, two university lecturers discuss their view about the riots. They both agree that the locals need the British to maintain peace in the country. They are of the opinions that the natives should be thankful to them for bringing progress to the country. This hegemony towards the west still exists in many nations and countries until this moment.

However, the novel ends with a letter to Sabran in Malaya Two years have passed and Peter writes to Sabran to tell him of his plan to return to Malaya. Peter reveals that England is not as he once thought. He realizes that he truly belongs to Malaya.

The novel is full of issues that reflect a sense of belonging to the migrant's homeland. For instance, in the novel, uncle Rasu and his family leave Malaya to their homeland, India, when they realize that Malaya is not safe for them because of the political unrest that has appeared. Although he stayed in Malaya for a long time, his sense of belonging is still to India. He does not consider Malaya as his land in which he must live for good or bad. This can obviously be seen in when the narrator of the story describes the last moments of uncle Rasu before he leaves Malaya: "The taxi crept through the evening crowd of anonymous creatures in the suburb. Rasu recognized a face here, a crony there. They had been the props of his existence. He felt no regret at leaving; in fact he was anxious to leave" (Fernando 1992:12).

In addition to that, Rasu believes that people in Malaya are not his original nation, India. For instance, he utters that "something is going to happen, Rasu thought. Bukit Mertajam and Ipoh. It's not safe to be here. It's better to be among our own people" (Fernando 1992:13). In fact, this is one of the problems that diaspora people experience in the hostland. They live in the land of domicile, but they still belong to their ancestral land as well as practice their own culture and traditions. This confirms what has been elaborated by Renan as discussed earlier that "a nation is a soul, a spiritual principle" (Renan 1990:19, in Bhabha 1990:19). It is not merely the place of residence or people around, but it is the land that a person feels. Just like Rasu, Peter has no sense of belonging to Malaya as quoted below:

"I mean you too, Santi," Peter said. "You're a bloody foreigner. As for where I'm going, why to England, of course. They're a bit more civilized there. I'll get a job there, maybe as a teacher, marry and settle down and live to a ripe old age. You buggers can agitate and demonstrate fight it out amongst yourselves."(69).

Peter wants to leave Malaya and lives in England. He believes that due to his color and thinking, he cannot assimilate himself in Malaya. This is because the Malayan people consider him as Eurasian because he is white. This reinforces the idea that he does not belong to Malaya. However, he sometimes utilizes a colonial language such 
Mar-Apr 2020 /Available online: https://ijels.com/

as "civilized" that is repeatedly uttered by the colonizers to describe the west and to make it in a binary opposition with the east which is always depicted as "uncivilized". Peter's sense of belonging to England can be obviously seen in the quotation above when he argues with Santinathan about his intention to go to England. Peter believes in the hierarchy of the west. He seems to be convinced that the British have the right to colonize Malaya. This can be realized when he criticizes the slogans that are raised by some of the demonstrators such as "British Realty is sucking our blood"(23). He reveals that if he was the governor, he would "line them up and shoot the bloody lot of them"(23). The pronoun 'them' refers to the nationalists who call for liberty.

By the same token, the novel deals with nationhood and nationalism. Since the story is set in a time when Malaya was colonized, the national movements are given a wide space in its plot. This can clearly be understood when the Malay student, Sabran, does not believe what the British reveal about the natives. In fact, he knows that the colonizers always attempt to divide the natives by spreading rumors about each other. These rumors are utilized to make the natives disunited. Sabran says that "now there's a rumour spreading that British Realty do not want to see us united. That they have planted agents to cause trouble between the unions. So long as we remain disunited, they can remain on top. So they say. But that's not all"(59). This except shows that Sabran is aware that the unity of the natives is one of the elements that lead to liberty. Therefore, he always reinforces his relationship with his friends who are of different races such as Santinathan and Guan Gheng. It seems that the three friends symbolize the main three races in Malaya. Sabran is Malay, Guan Kheng is Chinese, and Santinathan is Indian. However, Sabran's intention of making people united regardless of their races reinforces what has been discussed in the article earlier in which the "National Young Lawyers Committee chairman Edmund Bon said his group had started conducting a survey on national unity among young Malaysians" (The Star 2007). Sabran tries his best in order not to lose his friendship with Santinathan, even though the latter say harmful words that hurt his feeling. In other words, he portrays what the different races must do in the real life. They need to forget their minor problems and unite together. However, Sabran's argument about his friend, Santinathan, can clearly be realized in the quotation below:

Ever since Santinathan had come to stay in his Kampung near Endau, Sabran had come to a conviction that whatever Santinathan said or did could never separate them. They had found an incredible way, not simply through language, of making their differing backgrounds respond to each other in mutual sympathy.(59).

In fact, Sabran is a hybrid character i.e. he can easily live with people of other races. He even enjoys his life in the Malayan multicultural society. For instance, "when he won a scholarship to Raffles Institution he went to live with his uncle who was a lorry driver in Singapore. It was exciting to go to school with classmates of different races and it was there he met Santinathan"(60). Fernando's portrayal of Sabran makes him a good example for Malayan people.

In contrast, the situation becomes worse when the different races refuse to live together. In other words, the races that exist in Malaya have to forge a new nation that contains all of them. They must be proud of their new land and nation which have some elements from the values of each race and culture. Thus, they can work together to liberate and develop Malaya. This can be obviously seen when Santinathan illustrates that the different races may have troubles because they "don't know how to live together"(61). In other words, the different races must accept each other because the land welcomes all of them. Therefore, they have to protect it. They need to liberate it from the colonizers.

However, Sally, whom is depicted as a prostitute in the story, symbolizes the land itself. Like the land, she merely gives love to people but no one loves her in return. In fact, this figurative language conveys a significant meaning. Sally and the land seem to be the same. For instance, Sally accommodates people, but they do not please her in return. On the other hand, the land welcomes the different races, but they refuse to unite to liberate it when it has been colonized. This can be clearly understood from Sally's anger in the quotation below:

Why must I only give, why should they not love me in return? Why do they take, hurting? Why can't they take with love? Why do they find that so difficult? I have taken whoever came to me, so often without money. I have given love so freely. I thought I had patience to wait even until I die to find someone who would love me.(86).

Although Sally takes some money from people who come to her, she believes that she gives them love in return. This can be realized from her response to Sabran when her friends abandon her when she has been raped. She says; "you mean what I'm doing is not love because they give me a little of money? It's love. Maybe I never see most of them again, but when they're with me, I give them a little love" (120). These sentences support the idea that Sally is a 
Mar-Apr 2020 /Available online: https://ijels.com/

symbol of the land. She loves people, but they do not love her in return. In addition to that, Sally reflects the real life in Malaya in the 1950s when there was unrest between the different races i.e. racial riots. This has been clearly portrayed in the excerpt below.

Even the rough ones I give them a little love. They are frightened, all of them, as if they are running away from something and want to rest. Malays, Chinese, Indians, Eurasians, I give them rest, I know they are confused, they talk bad of one another sometime-sometimes even they get very angry. But when they are with me they become calm, they don't argue, they don't talk. (120).

In fact, the author utilizes Sally in the novel to address some national issues such as nationhood and nationalism. He wants to make the races love the land which welcomes them the same way that Sally welcomes and loves people who come to her. Even though the land is colonized and Sally is raped, the land still welcomes people and Sally still welcomes her customers.

Living among people who possess different culture, language, myths, or goals creates a sense of loss, alienation, and racial prejudice. This makes the migrants live in between spaces; they neither belong to the new nation, nor to their own nation. For instance, the Chinese, Indians and Eurasians, who sailed to Malaya, have suffered a lot from identity's problems and a sense of loss. To them, Malaya is a new land with different language, religion, culture, history, experience and race as well. The experience of losing their original identity is so painful, especially to those who feel proud of their ancestral land, nation, culture ... etc. Due to the limitation of space and time, this essay does not deal with the whole problems of identity that the migrants experience in Malaya. It merely analyzes the experience of living in between spaces, racial prejudice and alienation as discussed in the forthcoming paragraphs.

Peter in the story lives in between spaces. He lives in Malaya, but he is not comfortable because his sense of belonging is still to England. This can be seen when he leaves Guan Kheng's car. He leaves them to save them the troubles for his existence with them attracts the attention of the attackers towards them. In fact, he is discriminated because he is Eurasian. For instance, when his friends think that he feels frightened when he is alone, he replies; "I'm alone you think I'm afraid to be alone, I'll show you. Just let me get out of this place as quickly as possible, and forget it ever existed"(82). The word 'place' in the quotation above refers to the car and Malaya as well. However, Peter prefers to go to England and live there, although he was born in Malaya and he does not know any people in England. Peter's experience of living in between spaces can obviously be seen when Santinathan asks him why he wants to leave Malaya and live in England: "Ask yourself then what are you afraid of. You are afraid of something, aren't you? Have you ever asked yourself why? You where born here. You have lived here all your life. Yet you prefer to go and live among people you don't know. Why?"(142). Just like Peter's experience of living in between spaces, Santinathan also shares Peter some of that experience. For instance, he reveals that he does not agree with his father's decision to leave India and migrate to Malaya. In fact, his father and family have left their culture, land and people to live in a new land, Malaya, with different people and culture. His father died in Malaya by a Japanese bomb. He had come to search for a safe land, but unfortunately he came to die in Malaya. In fact, this can clearly be observed in the excerpt below in which Santinathan recalls his father's suffering in Malaya during the Japanese colonization:

"Poor father," he said. "I wonder what he had in mind when he brought us over to Singapore. And what did he get out of it? A Japanese bomb that blew off the side of his face. He thought he was doing us a favour; actually he came here simply to die. And now that he's dead, the family's gone back. There's a kind of beautiful pointlessness about it. What a rotten deal for a man to have had. And what would he say if he saw us now.(52).

The quotation above shows the difference between the decision of Santinathan's father when he brought the family to Malaya and Rasu's decision to leave Malaya with the family and go back to India. However, they have left Santinathan and Neela in Malaya. Thus, the whole family lives in between spaces. They are not sure which place is their land. They love Malaya at the beginning but leave it when it is not safe.

Since Peter is a Eurasian, he is completely discriminated by people in the novel. One day, he is attacked just because of his color. In other words, the narrator of the story reveals that Peter is attacked because "he's classed with the Europeans. And not only him - all the Europeans too" (72). This racial discrimination is one of the current issues that the Malaysians try their best to get it out of the people's minds. For instance, the three organizations call for a "rejection of any ideology that uses racism to promote national unity" (The Star 2007). Although Peter was born and brought up in Malaya, people still classifies him as European. This racial prejudice practiced against Peter can easily be understood from the 
Mar-Apr 2020 /Available online: https://ijels.com/

dialogue between Santinathan, Sally, and Peter in the quotation below.

Santinathan said, "Peter, what happened?

"He was beaten up."

"Peter, are you all right?"

Peter turned and looked at him with eyes.

His face was discoloured with bruises, part of his scalp was matted with dried blood, his underlip was swollen.. Sally sponged his forehead with a wet a handkerchief. "I'm getting out of this damn place," he muttered, and turned his head away. (67).

The apartheid that Peter experiences leads him to decide to leave Malaya. For instance, in the excerpt above, he says; "I'm getting out of this damn place"(67). In addition to his experience of being discriminated by the ordinary people in the country, his close friends consider him as European. However, his friends are afraid that they are attacked because they are with him. Therefore, as discussed earlier, he leaves Guan Kheng's car in the middle of their way home in order to save his friends the troubles. In his conversation with them, Peter says, "I think you'd better drop me here. You'll be able to get home more safely that way"(81). Thus, he is racially discriminated even by his close friends.

In fact, Peter begins to feel that they are not his friends that he knows. For instance, when he leaves the car, he speaks to them "as though to a complete stranger. The years they had spent as contemporaries in school and university appeared suddenly to be paltry an excuse for their continuing friendship"(81). This prejudice reinforces his decision and intention to leave Malaya. Peter also feels alienated because the society stereotypes him as "a complete stranger", as though he was not born in Malaya. This can apparently be seen in the quotation below where Peter expresses his sadness when people alienate him:

"Here, as these men looked at me - At me, Peter burst in feverishly. "Not any of you. Me. Their look made me feel for the first time such a complete stranger - as if I was a creature made in the likeness of someone they did not know, whom they feared because he was so wholly foreign to them. I was an alien. Why? When we were eating that rojak - which by the way for the first time I didn't enjoy - I saw the point suddenly.(69).

Peter's experience of racial prejudice and alienation makes him believe that he does not belong to Malaya. For instance, he says, “I don't belong here. I don't really know anybody here, and what's more with the British getting out; I don't want to. I am getting out too"(69). As a result, at the end of the story he travels to England and stays there.

\section{CONCLUSION}

The discussions and analysis in this essay conclude that the issues of nationhood and nationalism have evidently been exposed in Fernando's Scorpion Orchid. Sabran attempts to unite the students from different races in one union to liberate Malaya from the colonizers. He strengthens his relationships with his friends and confirms that all people from different races should accept each other and live together. Similarly, Sally can be seen as a symbol of the land for she loves all people who visits her the same way that Malaya loves the different races who inhabit it. Even though Sally and Malaya have happily welcomed the different races, both have not been given love in return. However, Peter's suffering of racial prejudice and discrimination symbolizes the Eurasians of Malaya at that time when they were discriminated and stereotyped as Europeans just because they are white. As a result of the prejudice and alienation, Peter feels that he does not belong to Malaya and decides to travel England at the end of the novel. Just like Peter, Santinathan's uncle and family leave Malaya and return to their homeland, India.

In short, the novel is one of the marvelous novels that portray the society of Malaya in 1950s. It mirrors the experiences of the different races who lived in Malaya mainly the Malays, Indians, Chinese and Eurasians. In other words, the novel uncovers the identity problem of those races including their sense of belonging and living in between spaces.

\section{REFERENCES}

[1] Abraham, Collin. (1997). Ideology in the Early Colonial Period. In The Roots of Races Relations in Malaysia. Kuala Lumpur: Insan. 13-34.

[2] Bhabha, Hommi. K. (ed.). (1990). Nation and Narration. London: Routledge.

[3] Brennan, Timothy. (1990). The national longing for form. In Bhabha, Hommi. K. (ed.). (1990). Nation and narration. London: Routledge: 44-70.

[4] Koh, T. A. (2001). The empires' orphans: stayers and quitters in a bend in the river and Scorpion Orchid. In Quayum M. \& Wicks P. (ed.). Malaysian literature in English: a critical reader. Petaling Jaya: Pearson Education Malaysia. 154-167.

[5] Fernando, Lloyd. (1992[1976]). Scorpion Orchid. Kuala Lumpur: Times Books International.

[6] McLeod, John. 2000. Beginning Postcolonialism. Manchester: Manchester University Press. 
Mar-Apr 2020 /Available online: https://ijels.com/

[7] Merican, Fadillah et al. 2004. Lloyd Fernando. In Voices of Many Worlds. Selangor Darul Ehsan: Times Editions. 11527.

[8] Quayum, Mohammad. (2001). Shaping a New national Destiny with Dialogic Vision: Fernando's Green is the Colour. In Quayum M. \& Wicks P. C. (ed.). Malaysian literature in English: a critical reader. Petaling Jaya Pearson Education Malaysia. 168-129.

[9] Quayum, Mohammad. (2006). Lloyd Fernando. http://www.litencyc.com/php/speople.php?rec=true \&UID=1 $\underline{510}$ (accessed on 13/4/2020).

[10] Rifaat, Kamaludin (1966). The Arabic Nation (A lecture conducted in Ein Shams University in Egypt). http://alnaserynewspaper.tripod.com/kamal.htm (accessed on 20/4/2020).

[11] The Star Online. (2007). Groups: reject racist ideas. The Star. $\quad$ http://thestar.com.my/news/story.asp?file= /2007/4/25/nation/17539463\&sec=nation (accessed on 20/4/2020).

[12] Williams, Raymond. (1983). The Year 2000. New York: Pantheon.

[13] Wikipedia. (2020). Malaya. https://en.wikipedia .org/wiki/Malay_Peninsula (accessed on 20/4/2020).

[14] Zarzour, Adnan M. (1999). (ed.). The origins of the national and secular thinking. Beirut: The Islamic Office.

[15] Zuraiq, Gastanteen. (1994). The red book. Lebanon: Center of the Arabic Unity Studies. http://www. asharqalarabi.org.uk/center/rijal-zraiq.htm (accessed on 20/4/2020).

[16] Lyn, Cheah. W. (2006). Master Thesis. National University of Malaysia. 